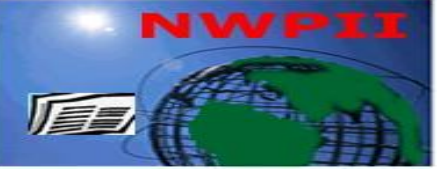

American Journal of Bímedical Sciences

ISSN: 1937-9080

nwpii.com/ajbms

\title{
COX-2 as a Potential Target in Chemoprevention of Benzo(a)pyrene Induced Lung Carcinogenesis in Mice-combined Role of Curcumin and Quercetin
}

\author{
Praveen Nair ${ }^{1}$, Anshoo Malhotra ${ }^{1}$ and Devinder K Dhawan* ${ }^{1}$ \\ 1-Department of Biophysics, Panjab University, Chandigarh 160014, INDIA \\ * Corresponding Author \\ Dr. D.K Dhawan, \\ Professor \\ Department of Biophysics \\ \& Coordinator, Centre for Nuclear Medicine \\ Panjab University \\ Chandigarh, India \\ Mobile: +91-9815979035 \\ Office: 0172-2534119, 2534121, 2534123 \\ Email: dhawan@pu.ac.in
}

Received: 9 December 2011; | Revised: 3 January 2012; | Accepted: 25 April 2012

\begin{abstract}
The present study was undertaken to assess the cumulative effects of curcumin and quercetin in inhibiting the activity of COX-2 alongwith other biophysical parameters such as ${ }^{3} \mathrm{H}$ thymidine uptake as well as uptake and turnover of ${ }^{14} \mathrm{C}$-glucose during $\mathrm{BP}$ induced lung carcinogenesis in mice. The mice were segregated into five groups viz., normal control, BP treated, BP + curcumin treated, BP + quercetin treated and $\mathrm{BP}+$ curcumin + quercetin treated. Lung carcinogenesis was induced by a single intra-peritoneal (IP) injection of BP $(100 \mathrm{mg} / \mathrm{Kg}$ body weight). Curcumin and quercetin were supplemented to mice at dose levels of $60 \mathrm{mg} / \mathrm{Kg}$ body weight and $40 \mathrm{mg} / \mathrm{Kg}$ body wt in drinking water, respectively. All the treatments were continued for a period of 22 weeks. BP treatment brought about a significant increase in the activities of COX-2. Supplementation of phytochemicals individually as well in combination to BP treated mice brought about moderation in the enzymatic activity which was restored to within normal limits. Further, BP treatment recorded increased ${ }^{3} \mathrm{H}$ thymidine uptake as well as enhanced ${ }^{14} \mathrm{C}$-glucose uptake and its turnover which were reduced significantly following simultaneous treatment with phytochemicals. Therefore, cumulative treatment with curcumin and quercetin has the potential of providing protection against lung cancer by inhibiting the COX-2 activity and moderating the ${ }^{3} \mathrm{H}$ thymidine uptake as well as ${ }^{14} \mathrm{C}$-glucose uptake and its turnover.
\end{abstract}

Keywords: inflammation, lung carcinogenesis, COX-2, ${ }^{3} \mathrm{H}$ thymidine uptake, ${ }^{14} \mathrm{C}$-glucose uptake and turnover. 


\section{Introduction}

Lung cancer is one of the leading causes of cancer deaths in developed countries and is also rising at an alarming rate in developing countries $[1,2]$ when compared to other cancers such as breast, colorectal and prostate cancer put together. Lung cancers are virtually undetectable for most of the time as they grow from a single cell to a noticeable lesion.

Environmental pollutants and tobacco smoke insult to the lungs create a unique environment which leads to certain inflammatory signals in the lungs capable of affecting a variety of processes like apoptosis, angiogenesis, immune response, and tumor invasion [3]. There is every possibility of initiation and development of carcinogenesis with the participation from the lung inflammatory, structural, and stromal cells. The role of COX-2, which is responsible for release of proinflammatory prostaglandin PGE1, in lung carcinogenesis, has been under the scanner for sometime now. COX-2 has been shown to regulate some aspects of tumor-associated angiogenesis and its expression has been previously reported to be present in elevated levels as compared to normal lung tissue [4-6]. Certain chemopreventive agents have the capability to affect the COX-2 expression as one of their many functions thereby paving the way for cancer chemoprevention. There are certain agents which have the capability of inhibiting COX-2 and thus have the potential to impart antitumor effects against lung cancer. Phytochemicals such as curcumin and quercetin are such chemopreventive agents which have the potential to affect the COX2 expression as well as its activity [7,8]. Hence, the present study was undertaken to elucidate the effects of phytochemicals namely curcumin and quercetin on COX-2 activity alongwith other biophysical parameters including ${ }^{3} \mathrm{H}$ thymidine uptake as well as uptake and turnover ${ }^{14} \mathrm{C}$-glucose during BP induced lung carcinogenesis.

\section{Materials and methods}

\subsection{Chemicals}

Benzo(a)pyrene (BP), curcumin and quercetin were procured from Sigma Aldrich company ( $\mathrm{St}$
Louis, MO, USA). COX-2 colorimetric kit was from Cayman's chemicals USA. ${ }^{3} \mathrm{H}$ labelled thymidine and ${ }^{14} \mathrm{C}$ labelled Glucose were procured from Board of Radiation Isotope Technology (BRIT), Trombay, India.

\subsection{Animals}

Male laka mice in the weight range of 18-20 $\mathrm{g}$ were procured from the central animal house, Panjab University, Chandigarh, India. The animals were housed in polypropylene cages under hygienic conditions in the departmental animal house strictly in accordance with the guidelines as outlined by the institutional ethics committee.

\subsection{Experimental design}

Animals were segregated into five treatment groups. Animals in Group I served as normal controls and were administered with corn oil (I.P) intraperitoneally, which was used as a vehicle for the treatment of animals in BP group. Animals in Group II to $\mathrm{V}$ were given a single injection (IP) of $\mathrm{BP}$ at a dose level of $100 \mathrm{mg} / \mathrm{Kg}$ body weight dissolved in corn oil [9]. Group III animals were given curcumin orally in water at a dose level of $60 \mathrm{mg} / \mathrm{Kg} / \mathrm{b}$.wt thrice a week [10]. Animals in Group IV were given quercetin orally in water at a dose level of $40 \mathrm{mg} / \mathrm{kg} / \mathrm{b}$.wt in water thrice a week [11-13]. Both the phytochemicals were given to animals using intubation gavage technique. Animals in group $\mathrm{V}$ animals were given a combined treatment of curcumin and quercetin in a similar manner as was given to group III and group IV animals respectively. The treatment with phytochemicals to the animal belonging to groups III to V was started 10 days prior to BP injection. All the animals had free access to the diet and water and the treatments continued for a total duration of 22 weeks.

\subsection{Body weight changes}

A careful record of body weight changes of normal control, BP, curcumin, quercetin and curcumin + quercetin treated animals was kept throughout the study. The animals were weighed at the beginning of the experiment, then weekly and finally before sacrificing them. A daily record of food as well as water intake was also maintained throughout the study period. 


\subsection{Lung tumor incidence and tumor multiplicity analyses}

After the terminal sacrifice following 22 weeks after BP treatment, lungs were removed from the mice, blotted dry and were examined for the visible macroscopic lesions. Tumors were easily discernable in the inflammated sections of the lung. The number of tumors was noted for tumor incidence and multiplicity studies

\subsection{Lung weight changes}

Following 22 weeks of BP treatment, the animals were sacrificed under ether anesthesia, lung excised and washed in normal saline. Lung weights were measured using Shimadzu Digital weighing balance.

Cox 2: Cox 2 enzyme activity was estimated by using Cayman's colorimetric assay kit.

Principle: Cayman's assay kit measures the peroxidase activity of Cox. It is assayed colorimetrically by monitoring the appearance of oxidized N, N, N', N'-tetramethyl-pphenylenediamine (TMPD) at $590 \mathrm{~nm}$. The kit includes isozyme-specific inhibitors for distinguishing Cox 2 activity from Cox 1 activity.

\subsection{Procedure}

$40 \mu \mathrm{L}$ of each sample was added to the sample wells containing $120 \mu \mathrm{L}$ of assay buffer and $10 \mu \mathrm{L}$ of heme. Further, $40 \mu \mathrm{L}$ of each sample was added to the inhibitor wells containing $110 \mu \mathrm{L}$ of assay buffer , $10 \mu \mathrm{L}$ of heme and $10 \mu \mathrm{L}$ of specific inhibitor for Cox 2 . The plate was shaken for a few seconds and was followed by incubation for 5 minutes at $25^{\circ} \mathrm{C}$. Then, $20 \mu \mathrm{L}$ of colorimetric substrate was added to each of the well and the reaction was initiated by the addition of $20 \mu \mathrm{L}$ arachidonic acid to each well. The plate was shaken again for a few seconds and was subsequently incubated at $25^{\circ} \mathrm{C}$ for 5 minutes. The absorbance was read at $590 \mathrm{~nm}$ by using a plate reader.

\subsection{Radioisotopic Studies}

\subsubsection{Uptake of ${ }^{3} \mathrm{H}$-Thymidine to assess rate of DNA synthesis:}

The rate of DNA synthesis was assessed in vitro by measuring the incorporation of ${ }^{3} \mathrm{H}$ Thymidine in the lungs of the normal control and treated animals. The lungs were sliced into very thin sections and the uptake of $\mathrm{H}$-Thymidine was measured in the weighed slices by tissue accumulation method of Crane and Mendelstam [14] .

$$
\text { In-vitro uptake of }{ }^{14} C \text {-D-Glucose : }
$$

The uptake of C-D-Glucose was measured in the weighed lung slices by following the tissue accumulation method of Crane and Mendelstam [14].

\subsubsection{Radiorespirometric determination of ${ }^{14} \mathrm{C}$ - glucose metabolism}

Radiorespirometric method is the most sensitive method of analytical procedures. The application of this method to the in vitro measurement of metabolism can be accomplished by supplying ${ }^{14} \mathrm{C}$-labeled substrates followed by collecting and measuring the radioactivity of the evolved ${ }^{14} \mathrm{CO}_{2}$. Since its introduction, the double vial technique for radiorespirometry has been widely used to measure the respiration of ${ }^{14} \mathrm{C}$ labeled substrates. In this technique, a small vial was placed inside a standard liquid scintillation vial to form two compartments. ${ }^{14}$ C-labeled glucose and the tissue sample were placed in one compartment (the inner vial) and the second compartment (the outer vial) contained a Whatman-I filter wick impregnated with scintillation flour and I N NaOH. ${ }^{14} \mathrm{CO}_{2}$ produced through respiration in the sample compartment was trapped on the wick and was measured directly in a liquid scintillation counter.

\subsection{Statistical analysis}

The statistical significance of the data has been determined using one-way analysis of variance (ANOVA) and a multiple post-hoc test of least significant difference (LSD). The results are represented as Mean \pm S.D. 


\section{Results}

\subsection{Body weight changes}

The deviation in the body weights of the animals subjected to different treatments from normal controls have been depicted in figure $\mathbf{1}$. The body weights of the normal control and treated mice increased progressively throughout the study. However, BP treatment resulted in a significant decrease in the body weights at the time interval twenty weeks when compared to the normal control mice. Supplementation with curcumin and quercetin individually as well as in combination improved the body weight growth in comparison to BP treated animals. Additionally, the daily food and water intakes were measured, and it was found that on an average 10-15 ml of water was consumed by each animal/day. However, no significant changes in food consumption were observed among various groups of animals.

A tumor incidence of about $89 \%$ was observed in the mice subjected to BP treatment (Table 1). When curcumin and quercetin were administered separately to BP treated mice, an appreciable decrease of about $12.5 \%$ and $21.3 \%$ respectively, in the tumor incidence was observed. Interestingly, combined treatment with these two phytochemicals was able to reduce the tumor incidence upto $32 \%$, signifying the advantage of combined treatment .The average number of tumors per tumor bearing mice (tumor multiplicity) was found to be 1.75 in BP treated mice. On the other hand, mice treated with curcumin, quercetin separately or in combination showed a decline in tumor multiplicity compared to mice administered with BP with levels of 1.42 , 1.28 and 1.00 , respectively.

\subsection{Lung weight changes}

Figure 2 describes the lung weights of normal controls and mice subjected to various treatments. A significant increase in the lung weights was observed after 22 weeks of treatment duration when mice were subjected to single dose of BP treatment. Separate treatments with curcumin and quercetin for 22 weeks were able to decrease significantly the lung weights.
Table 1 Effects of 22 weeks of curcumin and quercetin treatments on the on the incidence and multiplicity of mice subjected to BP treatment

\begin{tabular}{|l|l|l|}
\hline Groups & $\begin{array}{l}\text { Tumor } \\
\text { incidence } \\
\text { (\%age) }\end{array}$ & $\begin{array}{l}\text { Tumor } \\
\text { multiplicity }\end{array}$ \\
\hline Normal control & $\mathbf{0}$ & $\mathbf{0}$ \\
\hline Benzo(a)pyrene & 89 & 1.75 \\
\hline $\begin{array}{l}\text { Benzo(a)pyrene + } \\
\text { curcumin }\end{array}$ & $\mathbf{7 8}$ & 1.42 \\
\hline $\begin{array}{l}\text { Benzo(a)pyrene }+ \\
\text { quercetin }\end{array}$ & 70 & 1.28 \\
\hline $\begin{array}{l}\text { Benzo(a)pyrene }+ \\
\text { curcumin + quercetin }\end{array}$ & 60 & 1.00 \\
\hline
\end{tabular}

Effects of curcumin and quercetin on body weights of mice subjected to BP treatment

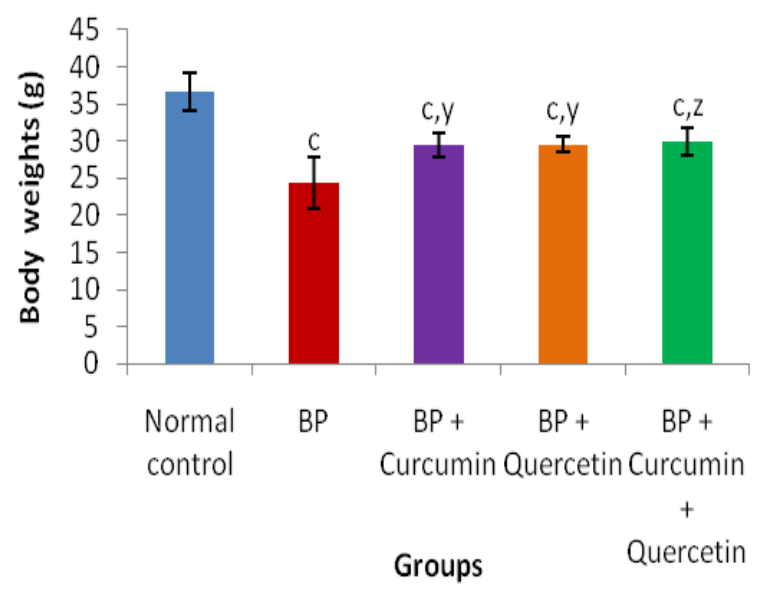

Figure 1. Data are expressed in Mean \pm S.D ${ }^{\mathrm{a}} \mathrm{P} \leq 0.05,{ }^{\mathrm{b}} \mathrm{P} \leq 0.01$ and ${ }^{\mathrm{c}} \mathrm{P} \leq 0.001$ by Least Significance Difference test when values are compared with normal control group ${ }^{\mathrm{x}} \mathrm{P} \leq 0.05,{ }^{\mathrm{y}} \mathrm{P} \leq 0.01,{ }^{\mathrm{z}} \mathrm{P} \leq 0.001$ by Least Significance Difference test when values of Groups III, IV \& V are compared with Group II

\subsection{Cyclo-oxygenase 2 enzyme activity levels (COX-2)}

Figure 3 depicts the enzymatic activity of cyclo-oxygenase 2 (COX-2), a proinflammatory enzyme in lungs of mice after 22 weeks of treatment schedule. BP treatment to mice brought about a statistically significant increase in the enzyme activity of COX-2 in the lungs of mice. 
Supplementation with quercetin and curcumin alone to BP treated mice for 22 weeks did result in a significant decrease in the activity of the proinflammatory enzyme. Further, when both the phytochemicals were supplemented simultaneously to BP treated mice, the enzyme activity of COX-2 was restored to within normal limits.

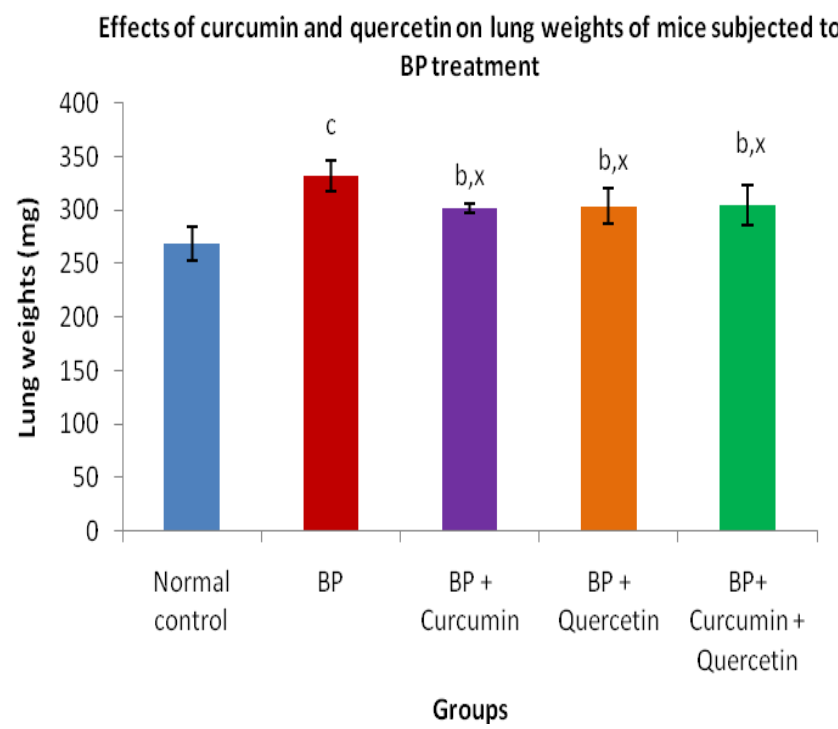

Figure 2. Data are expressed in Mean \pm S.D

${ }^{\mathrm{a}} \mathrm{P} \leq 0.05,{ }^{\mathrm{b}} \mathrm{P} \leq 0.01$ and ${ }^{\mathrm{c}} \mathrm{P} \leq 0.001$ by Least Significance Difference test when values are compared with normal control group

${ }^{\mathrm{x}} \mathrm{P} \leq 0.05,{ }^{\mathrm{y}} \mathrm{P} \leq 0.01,{ }^{\mathrm{z}} \mathrm{P} \leq 0.001$ by Least Significance Difference test when values of Groups III, IV \& V are compared with Group II

\subsection{Radiorespirometric determination of ${ }^{14} \mathrm{C}$ glucose turnover}

A statistically significant increase in the ${ }^{14} \mathrm{C}$ glucose turnover was noticed in the lungs of $\mathrm{BP}$ treated mice in the 22 weeks treatment schedule signifying increased glucose consumption of glucose due to faster cell proliferation (Figure 4). When quercetin and curcumin was supplemented separately to BP treated mice, there was some decrease in the ${ }^{14} \mathrm{C}$ glucose turnover which was not statistically significant. However, curcumin + quercetin combined treatment resulted in a significant decrease in ${ }^{14} \mathrm{C}$ glucose turnover when compared with BP treated group.

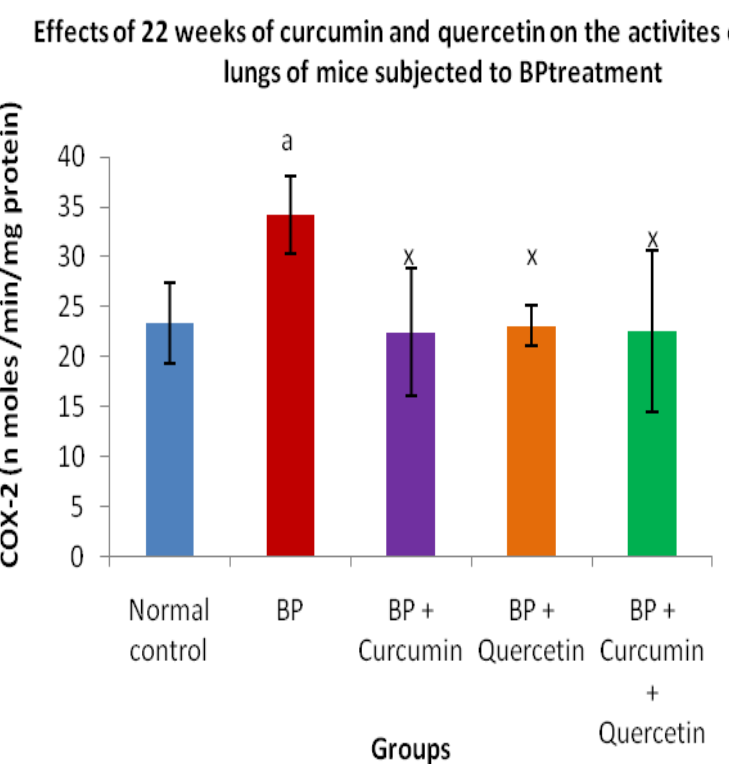

Figure 3. Data are expressed in Mean \pm S.D

${ }^{\mathrm{a}} \mathrm{P} \leq 0.05,{ }^{\mathrm{b}} \mathrm{P} \leq 0.01$ and ${ }^{\mathrm{c}} \mathrm{P} \leq 0.001$ by Least Significance Difference test when values are compared with normal control group

${ }^{\mathrm{x}} \mathrm{P} \leq 0.05,{ }^{\mathrm{y}} \mathrm{P} \leq 0.01,{ }^{\mathrm{z}} \mathrm{P} \leq 0.001$ by Least Significance Difference test when values of Groups III, IV \& V are compared with Group II

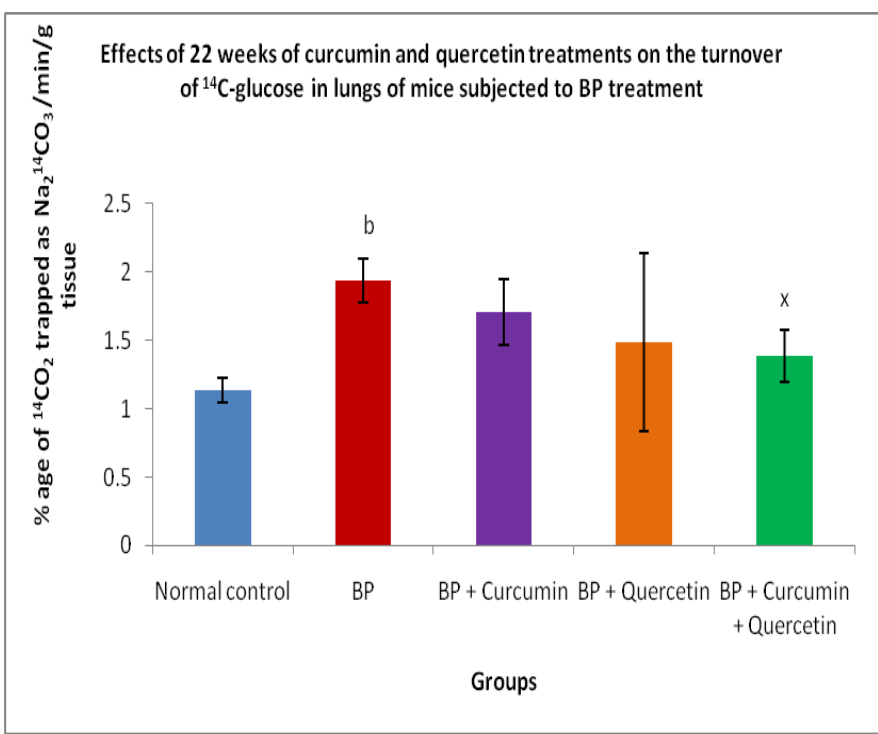

Figure 4. Data are expressed in Mean \pm S.D

${ }^{\mathrm{a}} \mathrm{P} \leq 0.05$, ${ }^{\mathrm{b}} \mathrm{P} \leq 0.01$ and ${ }^{\mathrm{c}} \mathrm{P} \leq 0.001$ by Least Significance Difference test when values are compared with normal control group

${ }^{\mathrm{x}} \mathrm{P} \leq 0.05,{ }^{\mathrm{y}} \mathrm{P} \leq 0.01,{ }^{\mathrm{z}} \mathrm{P} \leq 0.001$ by Least Significance Difference test when values of Groups III, IV \& V are compared with Group II 


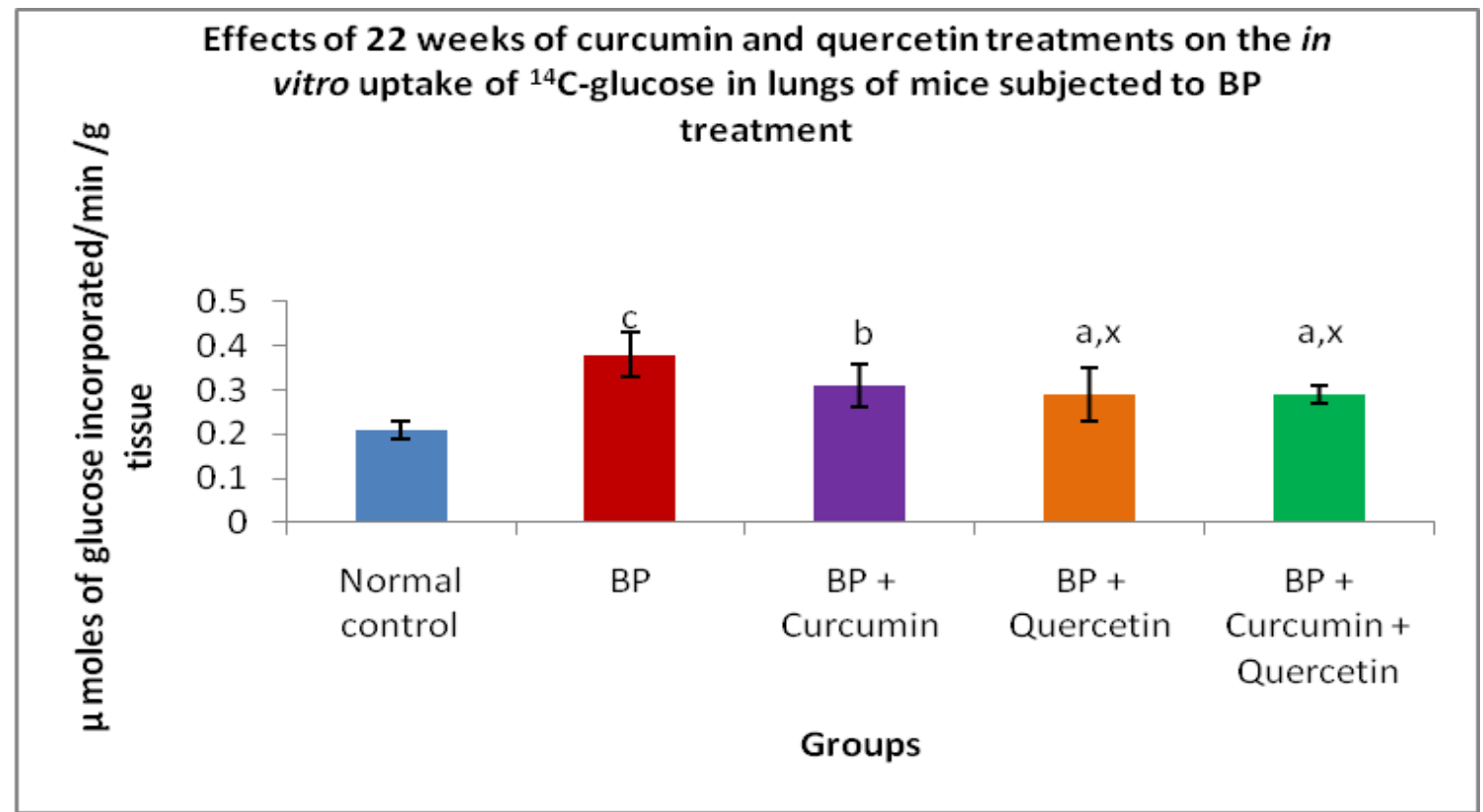

Figure 5. Data are expressed in Mean \pm S.D

${ }^{\mathrm{a}} \mathrm{P} \leq 0.05,{ }^{\mathrm{b}} \mathrm{P} \leq 0.01$ and ${ }^{\mathrm{c}} \mathrm{P} \leq 0.001$ by Least Significance Difference test when values are compared with normal control group

${ }^{\mathrm{x}} \mathrm{P} \leq 0.05,{ }^{\mathrm{y}} \mathrm{P} \leq 0.01,{ }^{\mathrm{z}} \mathrm{P} \leq 0.001$ by Least Significance Difference test when values of Groups III, IV \& V are compared with Group II

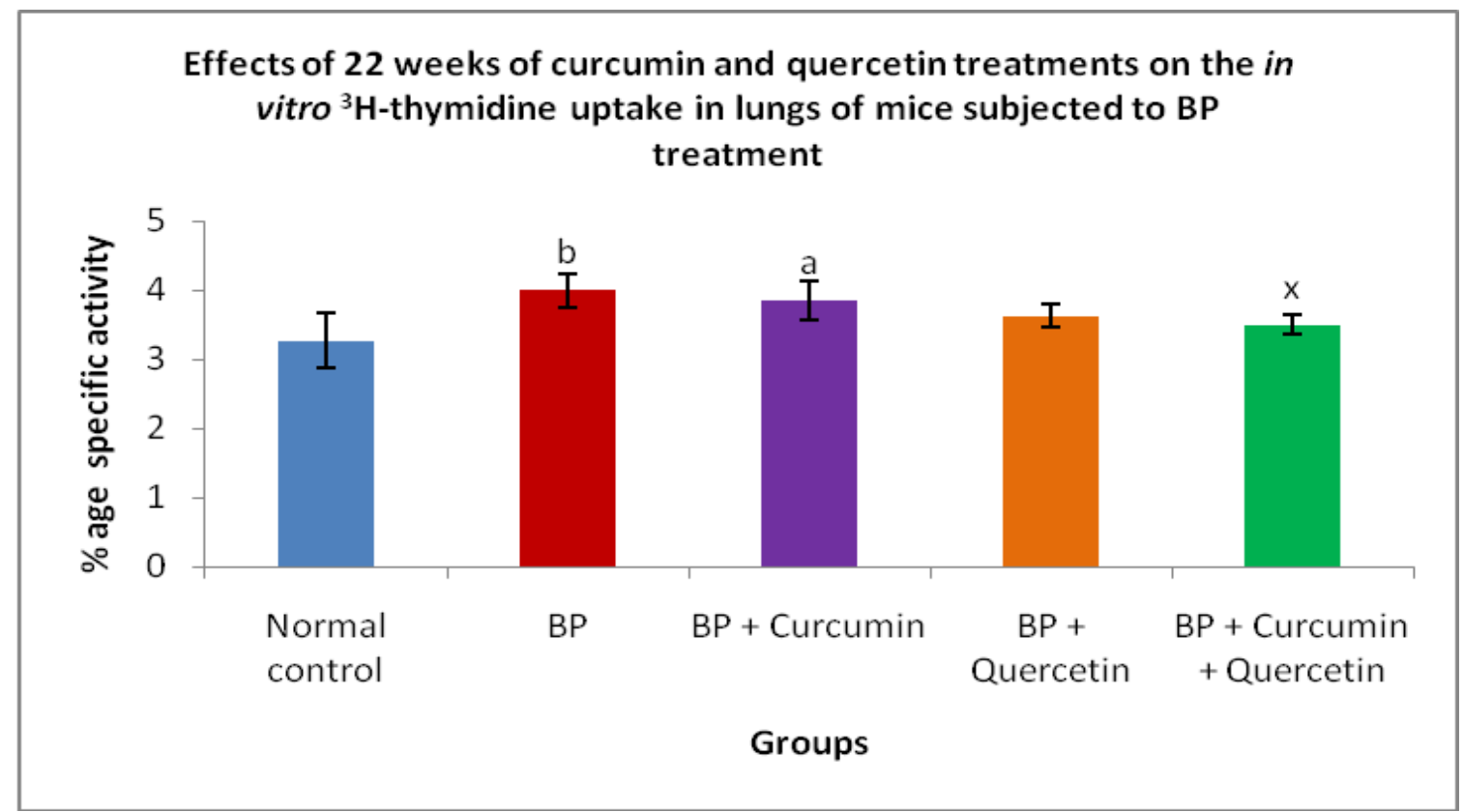

Figure 6. Data are expressed in Mean \pm S.D

${ }^{\mathrm{a}} \mathrm{P} \leq 0.05,{ }^{\mathrm{b}} \mathrm{P} \leq 0.01$ and ${ }^{\mathrm{c}} \mathrm{P} \leq 0.001$ by Least Significance Difference test when values are compared with normal control group

${ }^{\mathrm{x}} \mathrm{P} \leq 0.05,{ }^{\mathrm{y}} \mathrm{P} \leq 0.01,{ }^{\mathrm{z}} \mathrm{P} \leq 0.001$ by Least Significance Difference test when values of Groups III, IV \& V are compared with Group II 


\subsection{In vitro Uptake of ${ }^{14} \mathrm{C}$ glucose}

A statistically significant increase in the ${ }^{14} \mathrm{C}$ glucose uptake was noticed in the lungs of $\mathrm{BP}$ treated mice (Figure 5). When quercetin was supplemented alone as well as in combination with curcumin to BP treated mice, there was a significant decrease in the uptake values of ${ }^{14} \mathrm{C}$ glucose was observed. However, curcumin treatment alone also resulted in an appreciable decrease in the levels of ${ }^{14} \mathrm{C}$ glucose uptake in comparison to BP treated mice but the decrease was not statistically significant.

\subsection{Uptake of ${ }^{3} \mathrm{H}$-Thymidine:}

A statistically significant increase (Figure 6) in the uptake of ${ }^{3} \mathrm{H}$-thymidine was observed in the lungs of BP treated mice, signifying rapid DNA synthesis and proliferation of cells. However, supplementation with phytochemicals did cause a significant decrease in the ${ }^{3} \mathrm{H}$-thymidine uptake values when given in combination and individual treatments with phytochemicals did produce some decrease in ${ }^{3} \mathrm{H}$-thymidine incorporation the decrease it was not statistically significant

\section{Discussion}

The lungs are responsible for continuous uptake of oxygen and release of carbon dioxide and by doing so are exposed to toxins, pathogens and carcinogens present in the environment. There is every possibility that these inhaled agents might lead to oxidative injury and thus promote inflammatory responses [15]. This inflammatory response is responsible for combination of factors such as deregulated cell cycle, cytokines, and growth factors which can further lead to the development of lung cancer [16, 17]. The present study clearly demonstrates the potential of combined treatment of curcumin and quercetin in modulating pro-inflammatory enzyme COX-2 activity alongwith other biophysical parameters such as ${ }^{3} \mathrm{H}$ thymidine uptake as well as uptake and turnover of ${ }^{14} \mathrm{C}$-glucose during $\mathrm{BP}$ induced lung carcinogenesis in mice.

The body weights of BP treated mice were observed to be decreased. This decrease in body weights might be due to cachexia in which the tumor induces metabolic changes in the host leading to loss of adipose tissue and skeletal muscle mass [18]. When curcumin and quercetin were administered to BP treated mice separately as well as in combination, a significant improvement in the body weights was observed. Curcumin has been reported to reduce muscle wasting by inhibiting multiple proteolytic pathways [19]. Quercetin alongwith other polyphenols, through its activation of SIRT1 has been reported to be beneficial in calorie restriction, metabolism and skeletal muscle function [20].

Cyclo-oxygenase (COX) is a key enzyme responsible for conversion of arachidonic acid to prostaglandins (PGs) and other bioactive lipids, which in turn are involved in the regulation of normal growth responses and in aberrant cellular growth.COX has been demonstrated to exist in two distinct isoforms, $\mathrm{COX}-1$ \& $\mathrm{COX}-2$ respectively [21-23]. COX-1 is expressed in most tissues and performs a housekeeping function [24] to synthesize PGs with normal cell regulatory activity, particularly in the gastrointestinal tract. Conversely, COX-2 is an inducible enzyme which is mostly silent but considerably up regulated by a wide array of stimuli such as interleukin (IL)-1, tumor necrosis factor $\alpha$, platelet-derived growth factor, epidermal growth factor, lipopolysaccharide, and tumor promoters [25]. COX-2 has been shown to be implicated in the oncogenesis of many cancers [26] as constitutive expression of COX-2 is responsible for triggering the earliest steps of carcinogenesis. It has been reported that COX-2-deficient mice are more resistant to different forms of cancers [27] implicating its multi-step role in tumorigenesis, in early tumor promotion and in the late development of chemoresistance and metastatic formation [2831]. Preclinical studies do suggest that COX-2 may be involved in the molecular pathogenesis of some types of lung cancer. In lung cancer, COX-2 expression is observed at the majority stages of tumor progression. Clinical studies have demonstrated high levels of expression of COX-2 in almost all non small cell lung cancer preinvasive precursor lesions as well as invasive lung carcinomas, when compared to normal lung tissue [4-6]. Moreover, increased COX-2 expression is associated with a poor prognosis in 
lung cancer $[32,33]$. Consistent with the preclinical studies, BP induced lung carcinogenesis in mice also showed an increase in the activity of COX-2 enzyme in the present study. This can further be linked with an observed increase in lung weights of BP treated mice. As inflammation is linked with cancer development and progression [34-36], the resulting tumor incidence as well as multiplicity in the lungs of BP treated mice can be correlated with the high COX2 activity. Supplementation of phytochemicals significantly reduced elevated activity of COX-2 and further normalized the lung weights as compared to normal controls. Curcumin exhibits its anti-inflammatory effect in part, through inhibition of the NF-kappaB pathway and cyclooxygenase 2 (COX-2) enzyme and thus plays a pivotal role in suppressing tumor cell growth [8, 37]. Goel and co-workers [38] showed that curcumin inhibits COX-2 expression in HT-29 cells, thereby affecting the growth of these human colon cancer cells. Quercetin's inhibition of COX and lipo-oxygenase (LOX) has been suggested as a means of its anti-inflammatory actions [7, 39]. Also, quercetin has been linked to its inhibition of pro-inflammatory metabolites of arachidonic acid [40].

Radiorespirometric and uptake studies of ${ }^{14} \mathrm{C}$ glucose showed a significant increase in the uptake and turnover of ${ }^{14} \mathrm{C}$ - glucose in lung slices of BP treated mice. Also, ${ }^{3} \mathrm{H}$ thymidine uptake was significantly increased in the lung slices of BP treated mice. The above mentioned increase in the ${ }^{3} \mathrm{H}$-thymindine signifies increased DNA synthesis during rapid cell proliferation [41-43], which might be due to high activity of COX-2 and would have resulted in the slowdown of apoptotic machinery in BP treated mice. Also, increase in cell proliferations requires high amount of glucose to survive [44]. So, the observed increase in ${ }^{14} \mathrm{C}$ glucose uptake is a result of increase in requirement of glucose by rapidly proliferating cells following BP treatment. Combined treatment of curcumin and quercetin resulted in appreciable moderation in the uptake and turnover of glucose in the lungs of BP treated mice. The reason could be ascribed to the inhibition of COX-2 activity by phytochemical which induce apoptotic control over rapidly proliferating cells. The observation was confirmed by a decrease in the ${ }^{3} \mathrm{H}$-thymidine uptake an indicator of cell proliferation following supplementation of phytochemicals to BP treated mice. The decrease in ${ }^{14} \mathrm{C}$-glucose uptake and its turnover also gets substantiated when seen in context with decreased tumor incidence and multiplicity following combined supplementation of phytochemicals to BP treated mice.

Therefore, the study concludes that synergistic supplementation of curcumin and quercetin as a prophylactic therapy shall prove to be effective in containing hyperplasia by moderating COX-2 activity.

\section{Acknowledgements}

The authors greatly acknowledge the financial support rendered by Indian council of medical research (ICMR), India.

\section{References}

1. Behera, D.; Balamugesh, T. Lung Cancer in India, Indian J. Chest Dis. Allied Sci., 2004 46(4), 269-281.

2. Parkin, D.M.; Bray, F.I.; Devesa, S.S. Cancer burden in the year 2000: The global picture, Eur. J. Cancer., 2001a, 37, S4-66.

3. Peebles, K.A.; Lee, J.M.; Mao, J.T.; Hazra, S.; Reckamp, K.L.; Krysan, K.; Dohadwala, M.; Heinrich, E.L.; Walser, T.C.; Cui, X.; Baratelli, F.E.; Garon, E.; Sharma, S.; Dubinett, S. Inflammation and lung carcinogenesis: applying findings in prevention and treatment, Expert Rev. Anticancer Ther, 2007, 7(10), 1405-21. DOI 10.1586/14737140.7.10.1405

4. Hosomi, Y.; Yokose, T.; Hirose, Y.; et al. Increased cyclooxygenase 2 (COX-2) expression occurs frequently in precursor lesions of human adenocarcinoma of the lung, Lung Cancer, 2000, 30, 73-81.

5. Anderson, W.F.; Umar, A.; Viner, J.L.; Hawk, E.T. The role of cyclooxygenase inhibitors in cancer prevention, Curr. Pharm. Des., 2002, 8, 1035-62. DOI: $\underline{10.2174 / 1381612023394935}$ 
6. Fang, H.Y.; Lin, T.S.; Lin, J.P.; et al. Cyclooxygenase-2 in human non-small cell lung cancer, Eur. .J Surg. Oncol., 2003, 2, 171-7. DOI: 10.1053/ejso.2002.1316

7. Rivera, L.; Moron, R.; Sanchez, M.; Zarzuelo A.; Galisteo, M. Quercetin ameliorates metabolic syndrome and improves the inflammatory status in obese zucker rats, Obesity (Silver Spring), 2008, 16(9), 2081-7. DOI: $10.1038 /$ oby.2008.315

8. Aggarwal, B.B. Targeting inflammationinduced obesity and metabolic diseases by curcumin and other nutraceuticals, Annu. Rev. Nutr., 2010, 21(30), 173-99. DOI: 10.1146/annurev.nutr.012809.104755

9. Gunning, W.T.; Kramer, P.M.; Lubet, R.A.; Steele, V.E.; End, D.W.; Wouters, W.; Pereira, M.A. Chemoprevention of benzo(a)pyrene induced lung tumors in mice by the farnesyltransferase inhibitor R1157771, Clin. Can. Res., 2003, 9, 1927-30.

10. Swarnakar, S.; Ganguly, K.; Kundu, P.; Banerjee, A.; Maity, P.; Sharma, A.V. Curcumin regulates expression and activity of matrix metalloproteinases 9 and 2 during prevention and healing of indomethacininduced gastric ulcer, J Biol Chem., 2005, 280(10), 9409-15. DOI: 10.1074/jbc.M413398200

11. Dunnick, J.K.; Hailey, J.R. Toxicity and carcinogenicity studies of quercetin, a natural component of foods, Fundam. Appl. Toxicol., 1992, 19(3), 423-31. DOI: 10.1016/02720590(92)90181-G

12. Volate, S.R.; Davenport, D.M.; Muga, S.J.; Wargovich, M.J. Modulation of aberrant crypt foci and apoptosis by dietary herbal supplements (quercetin, curcumin, silymarin, ginseng and rutin), Carcinogenesis, 2005, 26(8), 1450-6. DOI: 10.1093/carcin/bgi089

13. Lamson, D.W.; Brignall, M.S. Antioxidants and cancer, part 3: quercetin, Altern Med Rev, 2000, 5(3), 196-208.

14. Crane, R.; Madelstam, P. The active transport of sugars by various preparation of hamster intestine, Biochim. Biophys. Acta., 1960, 45, 460-464. DOI: 10.1016/0006-3002(60)91482-7

15. Azad, N.; Rojanasakul, Y.; Vallyathan, V. Inflammation and lung cancer: roles of reactive oxygen/nitrogen species, J. Toxicol. Environ. Health. B. Crit. Rev., 2008, (1), 1-15. DOI:10.1080/10937400701436460

16. Weitzman, S.A.; Gordon, L.I. Inflammation and cancer: role of phagocyte-generated oxidants in carcinogenesis, Blood, 1990, 76, 655-663.

17. Engels, E.A. Inflammation in the development of lung cancer: epidemiological evidence, Expert. Rev. Antican. Ther., 2008, 8, 605-615. DOI: 10.1586/14737140.8.4.605

18. Tisdale, M.J. Wasting in Cancer, J Nut., 1999, 129 (1), 243S-246S.

19. Poylin, V.; Fareed, M.U.; O'Neal, P.; et al. The $\mathrm{NF}-\kappa \mathrm{B}$ Inhibitor Curcumin Blocks SepsisInduced Muscle Proteolysis, Mediators of Inflammation, vol. 2008, Article ID 317851, 13 pages, 2008. DOI:10.1155/2008/317851; 2008.

20. Chung, S.; Yao, H.; Caito, S.; Hwang, J.; Arunachalam, G.; Rahman, I. Regulation of SIRT1 in cellular functions: Role of polyphenols, Arch. Biochem. Biophys., 2010, 501(1), 79-90. DOI: 10.1016/j.abb.2010.05.003

21. Fu, J.Y.; Masferrer, J.L.; Seibert, K.; Raz, A.; Needleman, P. The induction and suppression of prostaglandin $\mathrm{H} 2$ synthase (cyclooxygenase) in human monocytes, $\mathrm{J}$ Biol Chem, 1990, 265(28), 16737-16740.

22. Xie, W.L.; Chipman, J.G.; Robertson, D.L.; Erikson, R.L.; Simmons, D.L. Expression of a mitogen-responsive gene encoding prostaglandin synthase is regulated by mRNA splicing, Proc. Natl. Acad. Sci. USA., 1991, 88(7), 2692-2696. DOI: 10.1073/pnas.88. $\underline{7.2692}$

23. Smith, W.L. Langenbach, R. Why there are two cyclo-oxygenase isozymes, J. Clin. Invest., 2001, 107(12), 1491-1495. DOI:10.1172/JCI13271

24. Kaur, P., Kaur, S., Kumar, S., Singh, P. Rubia cordifolia L. and Glycyrrhiza glabra L. Medicinal Plants as Potential Source of COX2 Inhibitors, Am. J. Biomed. Sci., 2010, 2(2), 108-120. DOI: 10.5099/aj100200108

25. Brown, J.R.; DuBois, R.N. Cyclooxygenase as a Target in Lung Cancer, Clin. Can. Res., 2004, 10, 4266s-4269s. DOI:10.1158/10780432.CCR-040014 
26. Cao, Y.; Prescott, S.M. Many actions of cyclooxygenase- 2 in cellular dynamics and in cancer, J. Cell. Physiol., 2002, 190(3), 279286. DOI: $10.1002 / \mathrm{jcp} .10068$

27. Langenbach, R.; Loftin, C.; Lee, C.; Tiano, H. Cyclooxygenase knockout mice: models for elucidating isoform-specific functions, Biochem. Pharmacol., 1999, 58(8), 1237-46. DOI:10.1016/S0006-2952(99)00158-6

28. Chulada, P.C.; Thompson, M.B.; Mahler, J.F.; Doyle, C.M.; Gaul, B.W.; Lee, C.; et al. Genetic disruption of Ptgs-1, as well as Ptgs-2, reduces intestinal tumorigenesis in Min mice, Can. Res., 2000, 60(17), 4705-8.

29. Tiano, H.F.; Loftin, C.D.; Akunda, J.; Lee, C.A.; Spalding, J.; Sessoms, A.; et al. Deficiency of either cyclooxygenase (COX)-1 or COX-2 alters epidermal differentiation and reduces mouse skin tumorigenesis, Can. Res., 2002, 62(12), 3395-401.

30. Akunda, J.K.; Chun, K.S.; Sessoms, A.R.; Lao, H.C.; Fischer, S.M.; Langenbach, R. Cyclo- oxygenase-2 deficiency increases epidermal apoptosis and impairs recovery following acute UVB exposure, Mol. Carcinog., 2007, 46(5), 354-62. DOI: 10.1002/mc. 20290

31. Sarkar, F.H.; Adsule, S.; Li, Y.; Padhye, S. Back to the future: COX-2 inhibitors for chemoprevention and cancer therapy, Mini. Rev. Med. Chem., 2007, 7(6), 599-608. DOI: $\underline{10.2174 / 138955707780859431}$

32. Gardner, B.; Zhu, L.X.; Sharma, S.; Tashkin, D.P.; Dubinett, S.M. Methanandamide increases COX-2 expression and tumor growth in murine lung cancer, FASEB J., 2003, 17(14), 2157-9. DOI: 10.1096/fj.03-0254fje

33. Mascaux, C.; Martin, B.; Verdebout, J.M.; Ninane, V.; Sculier, J.P. COX-2 expression during early lung squamous cell carcinoma oncogenesis, Eur. Respir. J., 2005, 26(2), 198-203. DOI: 10.1183/09031936.05. 00001405

34. Balkwill, F.; Mantovani, A. Inflammation and cancer: back to Virchow, Lancet, 2001, 357, 539-545. DOI: 10.1016/S0140-6736(00) $\underline{04046-0}$
35. Mueller, M.M. Inflammation in epithelial skin tumours: old stories and new ideas, Eur. J. Can., 2006, 42(6), 735-44. DOI:10.1016/j.ejca.2006.01.014

36. Adhami, V.M. Pancreatic Cancer and Inflammation, Am. J. Biomed. Sci., 2010, 2(4), 322-328. DOI:10.5099/aj100400322

37. Williams, C.S.; Mann, M.; DuBois, R.N. The role of cyclooxygenases in inflammation, cancer, and development, Oncogene, 1999, 18 (55), 7908-7916. DOI: 10.1038/sj.onc. $\underline{1203286}$

38. Goel, A.; Boland, C.R.; Chauhan, D.P. Specific inhibition of cyclooxygenase-2 (COX-2) expression by dietary curcumin in HT-29 human colon cancer cells, Cancer Lett., 2001, 172(2), 111-8. DOI:10.1016/S03043835(01)00655-3

39. Quercetin. Monograph, Altern Med Rev., 1998, 3(2), 140-3.

40. Murota, K.; Terao, J. Antioxidative flavonoid quercetin: implications of its intenstinal absorption and metabolism, Archives of Biochemistry and Biophysics, 2003, 417(1), 12-17. DOI:10.1016/S0003-9861(03)00284-4

41. Xiao, B.; Jing, B.; Zhang, Y.L.; Zhou, D.Y.; Zhang, W.D. Tumor growth inhibition effect of hIL-6 on colon cancer cells transfected with the target gene by retroviral vector, World. J. Gastroenterol., 2000, 6(1), 89-92.

42. Peng, Z.H.; Xing, T.H.; Qiu, G.Q.; Tang, H.M. Relationship between Fas/FasL expression and apoptosis of colon adenocarcinoma cell lines, World J. Gastroenterol., 2001, 7(1), 88-92.

43. Zhu, J.W.; Yu, B.M.; Ji, Y.B.; Zheng, M.H.; Li, D.H. Upregulation of vascular endothelial growth factor by hydrogen peroxide in human colon cancer, World J. Gastroenterol., 2002, 8(1), 153-157.

44. Shrivastava, G.C.; Quastel, J.H. Malignancy and tissue metabolism, Nature, 1962, 196, 876-880. DOI:10.1038/196876a0 